\title{
Jatkuvuutta, kumppanuutta ja pervoa biopolitiilkkaa hankalassa maailmassa
}

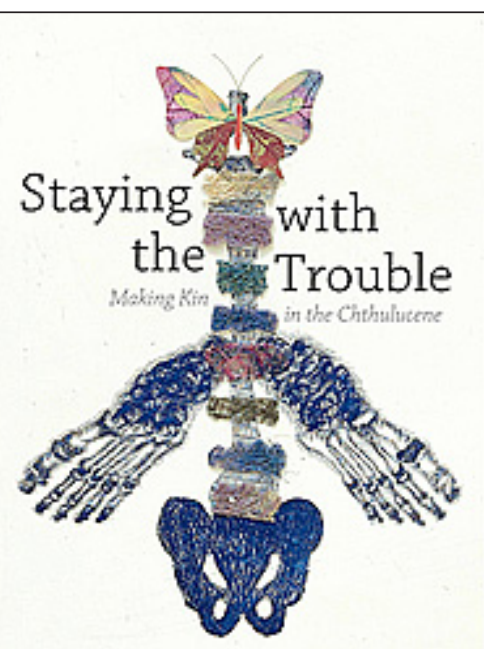

DONNA J. HARAWAY
Donna Haraway. 2016. Staying with the Trouble. Making Kin in the Chthulucene. Durham: Duke University Press, 296 s.

Donna Haraway on yksi niistä kirjoittajista, joiden teksteistä on vaikea olla inspiroitumatta. Hänen uusin kirjansa, Staying with the Trouble: Making Kin in the Chthulucene (2016), ei ole tässä poikkeus. Haraway on jo vuosia argumentoinut tarinoiden, kuvittelun ja "fabulaation" puolesta, mitä hän toteuttaa läpi tuotantonsa.

Tarinankerronta on keskeisessä roolissa myös Staying with the Troublessa. Kuten Haraway toistamiseen korostaa, tarinoiden kertomisella - sillä, mitä ja miten kerrotaan - on merkitystä. Juuri tarinoiden avulla voimme kuvitella ihmisten, asioiden ja olentojen välisiä monimuotoisia suhteita sekä spekuloida, miten nämä suhteet voisivat rakentua eettiselle pohjalle.
Teos koostuu kahdeksasta luvusta, joista kaikki lukuun ottamatta viimeistä "Camille stories" -lukua ovat enemmän tai vähemmän muokattuja versioita vuosina 2012-2015 julkaistuista teksteistä. Tarinoista rakentuvan verkoston osina ovat mukana esimerkiksi eläinten hyväksikäyttö lääketeollisuudessa, erilaiset taideprojektit sekä tieteisfiktio, joka toimii Harawayn tuotannossa merkittävänä ajattelun ja kuvittelun välineenä. Erityistä huomiota saavat feministisen tieteisfiktion pioneerien Ursula Le Guinin ja Octavia Butlerin tekstit. Harawaylle lyhenne "SF", jota yleisesti käytetään viittaamaan tieteisfiktioon (science fiction), ei kuitenkaan viittaa vain tähän lajityyppiin, vaan se on laajempi, metodologinen käsite, jossa tiivistyy Harawayn feministinen ajattelu. Kuten Haraway selittää: "An ubiquitous figure in this book is SF: science fiction, speculative fabulation, string figures, speculative feminism, science fact, so far." (s. 2)

Ihmiskunnan historian tarinan on Harawayn mukaan muututtava. On kerrottava tarinoita, joissa ihminen ei automaattisesti ole tarinan keskiössä, vaan erilaiset olennot ja kumppanuuslajit kulkevat tarinassa mukana. Haraway korostaa, että emme saa lannistua ja vaipua toivottomaan välinpitämättömyyteen maapalloa kohtaavien suurten ongelmien, kuten räjähdysmäisen väestönkasvun, edessä saati tuudittautua toiveikkaaseen
Pervosilmäys Arvostelut 
tulevaisuudenuskoon. Sen sijaan, kuten teoksen otsikossakin ilmaistaan, on pysyteltävä ongelmien tai "hankaluuksien" kanssa - ajateltava niiden kanssa tässä ja nyt. Ihmisten ja ei-inhimillisten olentojen väliset suhteet eivät ole ongelmattomia, mutta ihmisten on silti pyrittävä kehittelemään eettisempiä tapoja olla tässä hetkessä yhdessä ei-inhimillisten olentojen kanssa. Teoksen keskeisimmäksi iskulauseeksi muodostuukin: "Stay with the Trouble!"

\section{"[M]ultispecies flourishing on earth": kohti chthuluseenia}

Teos tähdentää, että elämme parhaillaan käännöskohdassa, jossa meidän on välttämätöntä kuvitella uudelleen suhteemme ei-inhimillisiin olentoihin. Miten suhteemme voisivat rakentua yhteistyölle sen sijaan, että pyrimme hallitsemaan kaikkea ei-inhimillistä? Haraway ehdottaa tutun, ihmisen toiminnan aiheuttamien muutosten aikakauteen viittaavan antroposeeni-käsitteen tilalle termiä "Chthulucene". Termin määritelmä kytkeytyy vastuullisuuteen, jossa ongelmia ei sivuuteta ja jossa meidän on otettava huomioon, miten olemassaolomme kietoutuu muihin maapalloa kanssamme asuttaviin olentoihin. "Antroposeeni" korostaa Harawaysta liikaa ihmisen näkökulmaa tilanteessa, jossa ihmisyyden rajat ja koko ihmiskunnan tulevaisuus tulisi radikaalisti määrittää uudelleen.

Haraway tähdentää, että termi ei tarkoita fantasiatarinoista tuttua lovecraftilaista (rasistiseksikin tulkittua) Cthulhu-hirviötä (huomaa erilainen kirjoitusasu), vaan lonkeromaisia ja lankamaisia eri asioiden ja olentojen välisiä yhteyksiä. Termin inspiraationa ovat hämähäkkilaji Pimoa cthulhu, myyttien Meduusa lonkeroineen sekä lankafiguurit, joissa sormiin kiedotuilla langoilla muodostetaan erilaisia kuvioita. Harawayn mukaan meidän tulisi ajatella omaa nykyhetkeämme sekä tulevaisuuttamme yhdessä eiinhimillisten olentojen kanssa. Miten voisimme kehittää sellaisia elämisen malleja, jotka olisivat eettisesti kestäviä kaikille maapallomme asukeille? Tähän kestävyyteen Haraway viittaa termillä "ongoingness", jatkuvuus.

\section{"[W]e are compost, not posthuman": pesäero posthumanismiin}

Haraway on hänen tunnetuimmasta tekstistään kyborgimanifestista (Haraway 1985) lähtien liitetty posthumanistiseen keskusteluun, jossa kritiikin kohteena on humanismin ihmis- ja toisinaan myös mieskeskeisyys. Hän on kuitenkin pyrkinyt erottautumaan posthumanismi-termistä. Eronteko vahvistuu Staying with the Troublessa, vaikka Haraway myöntääkin nauttineensa paljosta posthumanismin nimissä tehdystä työstä. Ihmisen (human) tilalle tulee "humus" (s. 11), ja käsite "posthuman" ("ihmisen jälkeen" tai "ihmisen jälkeinen") muuttuu höyryäväksi "kompostiksi" (s. 55, 97), jossa ihmiset ja ei-inhimilliset olennot ovat jatkuvassa vaikutussuhteessa. Nämä termit korostavat hänen mukaansa ihmisten ja ei-inhimillisten olentojen lonkeromaisia yhteyksiä ja sitä, miten ihmiset ovat jatkuvassa tulemisen ja "kompostoitumisen" tilassa erilaisten ei-inhimillisten olentojen kanssa.

Harawayn näkemys posthumanismista ei aivan istu omaan ymmärrykseeni kriittisestä tai feministisestä posthumanismista, joiden piirissä ihmisen ja ei-inhimillisten suhteiden kriittinen tarkastelu sekä niihin liittyvät eettiset kysymykset ovat keskiössä. Toisaalta post-humanismissa käsitteenä on myös ongelmia: "ihmisenjälkeisyys" herättää usein mielikuvia transhumanismiin kallellaan olevasta ihmisyyden teknologisesta parantelusta, joka jättää jalkoihin kaiken ei-inhimillisen. Siinä mielessä Harawayn pyrkimys tarjota posthumanismin tilalle uusia käsitteitä on ymmärrettävää.

\section{"Make kin, not babies!": pervoja perheitä ja biopolitiikkaa}

Ihmisen syrjäyttäminen etuoikeutetulta paikaltaan kytkeytyy myös biopolitiikkaan ja bioetiikkaan - siihen, keiden elämät ovat arvokkaita ja millaista lisääntymispolitiikkaa meidän tulisi tulevaisuudessa edistää. Haraway kritisoi feministejä siitä, että he eivät ole nostaneet tarpeeksi esiin ihmisten kasvavan väkiluvun tuottamia ongelmia. Jatkuvan väestönkasvun 
sijaan Haraway kehottaa meitä rakentamaan erilaisia "sukulaisuuksia" (engl. "kin"), jotka eivät rajoitu biologiseen reproduktioon. Haraway jatkaa tässä aiemmassa tutkimuksessaan esittelemällään linjalla, jossa erilaiset pervot perheet nousevat heteronormatiivisen lisääntymisen rinnalle.

Harawayn esimerkeissä ihmiset rakentavat suhteita erilaisten olentojen kanssa niin tieteessä, taiteessa kuin arjen eloonjäämiskamppailuissa. Tekstissä esiintyvät tuttuun harawaylaiseen tapaan erilaiset kumppanuuslajit aina perhosista ja puluista aiemmissakin teoksissa keskeisiin koiriin. Esimerkiksi Camille-tarinoissa uhanalaisten monarkkiperhosten kautta korostuu ihmisen vastuu ei-inhimillisten olentojen elinolosuhteista. Pulut (tai viestikyyhkyt) kumppanuuslajina nostavat esille erilajisten eläinten vaikutuksia ihmisten elämiin ja toimivat näin esimerkkinä ihmisen ja eläimen "yhdessä tulemisesta" (engl. becoming).

Kuten aikaisemmissa teksteissään (ks. esim. Haraway 2008), Haraway käyttää esimerkkinä kumppanuuseläintä omasta elämästään. Eräs teoksen kiinnostavimmista luvuista on "Awash in Urine. DES and Premarin in Multispecies Response-ability", jossa Haraway pohdiskelee koiransa Cayenne Pepperin estrogeenihoitoja, omaa turvautumistaan hoitoihin menopaussin aikana sekä tiineitä hevosia, joita on julmasti käytetty hyväksi Premarinnimisen hormonivalmisteen kehittelyssä. Luvussa ei-inhimillisten olentojen kohtelemisen etiikka, medikalisaatio sekä sukupuoli kytkeytyvät intersektionaalisesti toisiinsa herättäen monenlaisia kysymyksiä erilajisten eläinten hyvinvoinnin sukupuolittuneista edellytyksistä.

\section{"Think we must; we must think": feministit ajattelun edelläkävijöinä}

Tuntuu varsin sopivalta, että tarinankerronnan merkitystä korostava teos loppuu kaunokirjallisiin Camille-novelleihin, jotka ovat saaneet alkunsa kirjoitustyöpajassa elokuvantekijä Fabrizio Terranovan sekä psykologi, filosofi ja etologi Viciane Despret'n kanssa. Näissä Camille-tarinoissa (s. 134-168) visioidaan suuntaviivoja tulevaisuuden "kompostiselle" elämälle viiden ihmissukupolven ajan. Joillekin nämä visiot, joihin kuuluu muun muassa ihmispopulaation huomattava kutistuminen sekä ihmisten ja erilajisten eläinten symbioottinen yhteiselämä, voivat tuntua liian radikaaleilta. Sophie Lewisin (2017) mukaan Harawayn teos vaikuttaa jopa misantrooppiselta - eläimet asetetaan ihmisen edelle ja esimerkiksi rodun ja luokan kysymykset ohitetaan. Tulkitsen kuitenkin Harawayn pervoa biopolitiikkaa toisin. Haraway ei mielestäni unohda ihmistä; mikäli tuhoamme maapallon luonnonvarat on myös ihmisen tulevaisuus uhattuna. Sen sijaan esimerkiksi rodun tai vammaisuuden kysymyksiin teoksessa voitaisiin tarttua tiukemmin. Mikäli ihmisten määrää vähennetään, millaisia toimia se vaatii ja ketkä saavat jatkaa sukuaan?

Harawayn teos ei ole tyhjentävä vastaus siihen, miten esimerkiksi väestönkasvuun liittyvät ongelmat ratkaistaan. Teoksen tarkoitus tuntuu sen sijaan olevan haastaa meitä ajattelemaan. Yksi teoksen toistuva iskulause on Virginia Woolfia mukaillen: "Think we must; we must think!" Haraway rohkaisee etenkin feministejä tarttumaan toimeen, kehittelemään erilaisia kuvitelmia ja vaikuttamaan maapallon nykyhetkeen ja tulevaisuuteen:

$[\mathrm{M}] \mathrm{ultispecies} \mathrm{ecojustice} \mathrm{requires} \mathrm{feminists} \mathrm{to} \mathrm{exercise} \mathrm{leadership} \mathrm{in}$ imagination, theory, and action to unravel the ties of both genealogy and kin, kin and species. (s. 102)

Harawayn teos toimiikin parhaiten inspiroivana ajattelun apuvälineenä. Miten voisimme omilla tieteenaloillamme ja arjen valinnoissamme edesauttaa eettisempiä kohtaamisia ihmisten ja ei-inhimillisten välillä? Mitkä ovat ne ongelmat, joiden parissa meidän tulisi juuri nyt pysyä ja pyristellä tässä hankalassa maailmassa? 
Haraway, Donna J. 1985. "A manifesto for cyborgs: Science, technology, and socialist feminism in the 1980s". Socialist Review 80 (15:2): 65-107.

Haraway, Donna J. 2008: When Species Meet. Minneapolis: University of Minnesota Press.

Lewis, Sophie 2017: "Cthulhu plays no role for me". Viewpoint Magazine, 8.5.2017. https://www.viewpointmag.com/2017/05/08/cthulhu-plays-norole-for-me/\#rf38-7774 [haettu 1.6.2017] 